\title{
Correction to: A 2-Cys peroxiredoxin gene from Tamarix hispida improved salt stress tolerance in plants
}

Yuanyuan Wang, Zhongyuan Liu, Peilong Wang, Bo Jiang, Xiaojin Lei, Jing Wu, Wenfang Dong and Caiqiu Gao*

\section{Correction to: BMC Plant Biology 20, 360 (2020) \\ https://doi.org/10.1186/s12870-020-02562-6}

In the original publication of this article [1], the author indicates two errors in the article.

1. "CK: Tobacco plants transformed with empty pROKII; 35::Th2Cys: Tobacco overexpressing Th2CysPrx;" in the legend of Fig. 3 should be removed.

2. In the sentence "Fifteen lines were generated in the T0 generation.", "Fifteen" should be "Fourteen".

Published online: 19 August 2020

\section{Reference}

1. Wang, et al. A 2-Cys peroxiredoxin gene from Tamarix hispida improved salt stress tolerance in plants. BMC Plant Biology. 2020;20:360 https://doi.org/10. 1186/s12870-020-02562-6.

The original article can be found online at https://doi.org/10.1186/s12870020-02562-6.

* Correspondence: gaocaiqiu@nefu.edu.cn

State Key Laboratory of Tree Genetics and Breeding (Northeast Forestry

University), Harbin 150040, China

(c) The Author(s). 2020 Open Access This article is licensed under a Creative Commons Attribution 4.0 International License, which permits use, sharing, adaptation, distribution and reproduction in any medium or format, as long as you give appropriate credit to the original author(s) and the source, provide a link to the Creative Commons licence, and indicate if changes were made. The images or other third party material in this article are included in the article's Creative Commons licence, unless indicated otherwise in a credit line to the material. If material is not included in the article's Creative Commons licence and your intended use is not permitted by statutory regulation or exceeds the permitted use, you will need to obtain permission directly from the copyright holder. To view a copy of this licence, visit http://creativecommons.org/licenses/by/4.0/ The Creative Commons Public Domain Dedication waiver (http://creativecommons.org/publicdomain/zero/1.0/) applies to the data made available in this article, unless otherwise stated in a credit line to the data. 